\title{
POWIEDZ MI, CO JESZ, A POWIEM CI, KIM JESTEŚ - O KULINARIACH W SLOWENII
}

\author{
Słowa kluczowe: kulinaria, stereotyp, Słowenia, językowy obraz świata
}

Streszczenie. Kulinaria są ważnym składnikiem każdej kultury narodowej. Tekst ma na celu przybliżenie językowo-kulturowego obrazu słoweńskich kulinariów w perspektywie heterostereotypowej, widzianego oczyma Polaków. W analizie wykorzystano kategorie operacyjne wypracowane przez lubelską szkołę etnolingwistyczną i jej kontynuatorów z całej Polski. Bazę materiałową artykułu stanowią dane ankietowe. Wyróżniono i opisano dwa kręgi tematyczne, które współtworzą rekonstruowany obraz słoweńskich kulinariów: 1) ogólna charakterystyka kuchni w Słowenii, 2) konkretne dania, składniki, napoje itp. Tak ujęte badania językowego obrazu świata włączają się w dyskurs o tożsamości kulinarnej, będącej jednym z istotnych czynników wpływających na odrębność kulturową danej wspólnoty. Słownictwo z zakresu kulinariów, zwłaszcza uwarunkowane kulturowo, powinno więc znaleźć swoje miejsce w procesie glottodydaktycznym.

W obiegowym rozumieniu kuchnia - oprócz pomieszczenia, w którym przyrządza się posiłki, a także urządzenia do tego służącego oraz samego procesu gotowania - oznacza 'charakterystyczny dla danego kraju lub regionu zestaw potraw, gotowanych dań, napojów itp.; także: pożywienie, pokarm' (USJP II, s. 350). Przywołany w tytule tekstu aforyzm z napisanej w 1825 roku Filozofii smaku albo Medytacjach o gastronomii doskonatej (Brillat-Savarin 2015, s. 8) „ujmuje pożywienie i czynności jedzenia w wymiarze filozoficzno-kulturowym" (Witaszek-Samborska 2005, s. 7). Kuchnia jest bowiem istotną częścią egzystencji - nie tylko w znaczeniu biologicznym. Wypływa $\mathrm{z}$ wielowiekowych doświadczeń, dlatego nie bez przyczyny uznawana jest za jedną z cech narodowych.

Niniejszy tekst jest pewnego rodzaju refleksem tego, jak unikalna mozaika narodów i wyznań istniejąca na ziemiach obecnej Słowenii - lub mająca na nią wpływ - znalazła odzwierciedlenie w zwyczajach żywieniowych. Charakter kuchni występujący na tym obszarze formował się przez wieki. Nawyki i upodobania

*waclawek.maria@gmail.com, Univerza v Ljubljani, Filozofska fakulteta, Oddelek za slavistiko, Aškerčeva c. 2, 1000 Ljubljana, Slovenija, ORCID: 0000-0002-3307-5338.

** mariazofia.wtorkowska@ff.uni-lj.si, Univerza v Ljubljani, Filozofska fakulteta, Oddelek za slavistiko, Aškerčeva c. 2, 1000 Ljubljana, Slovenija, ORCID: 0000-0001-9317-2490. 
kulinarne kształtowały m.in. warunki klimatyczne, bogactwo świata roślinnego i zwierzęcego, pogańskie, a później chrześcijańskie obyczaje oraz wielowiekowa zależność od mocniejszych władców, sąsiadów. Dzieje obszaru stanowiącego obecną Słowenię, jak i terenów historycznie z nią związanych, służą budowaniu tradycji i tożsamości mieszkańców państwa, które po raz pierwszy na mapie politycznej Europy pojawiło się dopiero w 1991 roku. Z ową tradycją i tożsamością nieodłącznie wiąże się kuchnia. „Obyczaje kulinarne i praktyki związane z jedzeniem określają nas bowiem bardziej, niż możemy sobie zdać z tego sprawę [...]" (Borysławski 2002, s. 139).

Artykuł stanowi próbę eksploracji wybranego fragmentu językowego obrazu świata, a dokładnie językowo-kulturowego stereotypowego wizerunku kulinariów w Słowenii, postrzeganych z perspektywy Polaków. Stereotyp zgodnie z tradycją etnolingwistyki rozumiemy jako antropocentryczne, uogólniające i upraszczające wyobrażenie (koncept) opisywanego, ale i odpowiednio ocenianego obiektu, ,będące rezultatem interpretacji rzeczywistości w ramach społecznych modeli poznawczych" (Bartmiński 2007, s. 64). Temat niniejszego tekstu stanowi niewielki wycinek studiów, jakie prowadzimy nad stereotypem Polaka i Słoweńca w oparciu o badania ankietowe ${ }^{1}$. Opracowany przez nas kwestionariusz wypełniło 140 respondentów: 70 Polaków i 70 Słoweńców. Ze względu na specyfikę badań, konieczna jest krótka charakterystyka odpowiadających - dobranych na zasadzie dostępności, co wynikało z założenia o konieczności posiadania przez ankietowanych kontaktu z krajem własnym, jak i obcym oraz jego przedstawicielami. To w naszym przekonaniu daje miarodajne ujęcia auto- $\mathrm{i}$ heterostereotypowe. Na potrzeby artykułu heterostereotyp rozumiemy jako obraz rekonstruowany na podstawie zebranych przez nas danych pochodzących od Polaków.

Znaczną część respondentów stanowiły osoby płci żeńskiej w wieku produkcyjnym, mające wyższe wykształcenie. Wpłynęło to na wyniki, bowiem odzwierciedliło ich podmiotowy punkt widzenia i takąż perspektywę (Bartmiński 2009, s. 78-79). W przypadku polskich ankietowanych gros z nich to studenci (słowenistyki lub innych kierunków), którzy przyjechali do Słowenii w ramach wymiany, dużą grupę stanowili również przedstawiciele tamtejszej Polonii.

Z objętego badaniem materiału łącznie wydzielono 361 ekscerptów (100\%) na temat tego, jak Polacy postrzegają kuchnię w Słowenii. Eksploracja materiału pozwoliła na wyróżnienie dwóch głównych kręgów tematycznych: a) ogólna charakterystyka kuchni w Słowenii, b) konkretne dania, składniki, napoje itp., co wizualizuje wykres 1 .

${ }^{1}$ Por: Wacławek, Wtorkowska 2017a-c; 2018a-d; a-b. 
Wykres 1. Kulinaria w Stowenii - kręgi tematyczne

\section{Podział materiału}

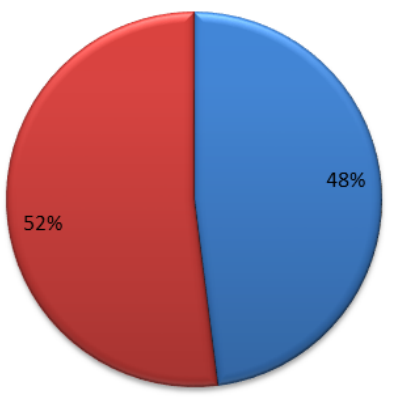

Ogólna charakterystyka kuchni w Słowenii

Konkretne dania, składniki,

napoje

Źródło: opracowanie własne

$\mathrm{W}$ analizie nie pomijałyśmy danych wskazywanych rzadko i jednokrotnie, uznając ich wartość ${ }^{2}$.

\section{OGÓLNA CHARAKTERYSTYKA KUCHNI W SŁOWENII}

Prawie połowa ekscerptów (48\%) ogólnie językowo dookreślała różnie postrzeganą l'art culinaire, jakiej w Słowenii doświadczyli Polacy biorący udział w badaniu.

Niewielki odsetek zebranych w tej grupie konkretyzacji explicite wyrażał, że zdaniem respondentów kuchnia występująca w kraju nad Drawą, Sawą i Soczą jest typowo słoweńska (3\%): ze Stowenią kojarza mi się [...] potrawy stoweńskie; słoweńskie desery; stoweńskie tradycyjne jedzenie; brak zamiłowania do zagranicznych kuchni, raczej pozostanie przy stoweńskim [...] menu³.

Mimo niewielkiego odsetka danych bezpośrednio wyrażających istnienie sztuki kulinarnej tego narodu, występująca w Słowenii kuchnia bywa pozytywnie wartościowana - głównie ze względu na doceniane walory smakowe $(3 \%)$ : potrawy słoweńskie sa bardzo smaczne; jedzenie jest pyszne; region śródziemnomorski powoduje, że kuchnia słoweńska jest smaczna, każdy poznany przeze mnie Stoweniec $w$ jakimś stopniu miat wyksztatcone preferencje smakowe nieograniczajace się do fast-foodów; bardzo dobra i różnorodna kuchnia; wydaje się, że Stoweńcy wybitnie cenia sobie dobre jedzenie, zwlaszcza domowe, przygotowane

\footnotetext{
${ }^{2}$ Takie założenie wynika również z dystansu do zastosowanej metody i sposobu badania.

${ }^{3}$ Relatywne zamknięcie na nowości czy też odmienności kulinarne widoczna jest raczej tylko u osób bardziej konserwatywnych. Postawa ta się zmienia (Cmiel i in. 2008, s. 45).
} 
własnoręcznie. Procent tego typu wypowiedzi nie był wysoki, choć semantycznie jest istotny.

Wśród innych atrybutów doświadczanej w Słowenii „swojskiej” kuchni (łącznie 6\%), nie zawsze niosącej treści o nacechowaniu melioratywnym, były:

- tradycyjność: tradycyjne potrawy; tradycyjne obiady; lubia [...] tradycyjne jedzenie; zamiłowanie do tego, co znane, niechęć do próbowania nowych potraw, chyba że przyrządzonych na stoweński sposób;

- obfitość: rodziny często spotykaja się przy suto zastawionym stole; porcje sa wielkie, nie do zjedzenia; Stoweńscy lubia ,, dobrze zjeść”;

- ciężkość: tradycyjnie ich kuchnia jest raczej ciężka; lubia ciężkie [...] jedzenie; ciężkostrawne potrawy; kuchnia tlusta;

- prostota, chłopskość: potrawy dość proste; tradycyjna kuchnia stoweńska jest prosta i uboga; najbardziej doceniana kuchnia chtopska.

Takie cechy narodowych rozkoszy stołu Słoweńców wynikają z historii (w tym braku słoweńskich rodów królewskich), dziedzictwa kulturowego. Tradycyjna domača kuhinja jest wprawdzie niezbyt wyszukana, ale sycąca.

Wskazane cechy przypisywane kulinariom krajan Petera Prevca właściwe są również dla tradycyjnego polskiego czy szerzej słowiańskiego modelu ${ }^{4}$. Potwierdzają to implicite i explicite wyniki badania. Niektórzy respondenci językowo wprost wyrazili zbieżność słoweńskiej i polskiej tradycji kulinarnej (2\%), ujawniając swoją polonocentryczną perspektywę: kuchnia zbliżona do polskiej; wydaje mi się, że upodobania kulinarne Stoweńców i Stowenek sq zbliżone do tych, które charakteryzuja Polaków; podobne jak w Polsce, z tym, że Stoweńcy bardziej szanuja jedzenie; kuchnia stoweńska ma trochę cech wspólnych z nasza polska, czyli nie [jest] taka lekka, jak oczekiwałam. Maja (pod innymi, słoweńskimi nazwami) bigos, gołąbi i rosót wołowy. Aluzyjnie przywołane w ostatnim cytacie nazwy potraw segedin golaž, sarma i goveja juha są podobne pod względem składników, choć przyrządza się je nieco inaczej niż w Polsce (por. Wacławek, Wtorkowska 2018d; Cmiel i in. 2008, s. 45).

Niewielka grupa ekscerptów (2\%) współtworzy kulturowo ważny rys wskazujący na pozytywnie ewokowane regionalne zróżnicowanie słoweńskich kulinariów: przywiazanie do lokalnych potraw; kultywuja kulinarne tradycje swojego regionu; $w$ zależności od regionu wyraźnie zróżnicowane potrawy specjalne; lokalnie - dla Sztajerców, czyli Styryjczyków - wizytówka jest olej z pestek dyni.

Wymienione do tej pory deskryptory i związane z nimi wyniki ilościowe, zwłaszcza niewielki procent danych językowych wprost nazywający kuchnię występującą w Słowenii jako słoweńską, korelują z największym odsetkiem wskazań tworzącym model słoweńskiej sztuki kulinarnej jako swoistej, zaczerpniętej od sąsiadów mieszanki bałkańsko-włosko-austro-węgierskich tradycji (17\%):

\footnotetext{
${ }^{4}$ Zob. też.: Wacławek, Wtorkowska 2018d.
} 
mozaikowa mieszanka wptywów wielu sasiednich krajów; dominuje kuchnia zaczerpnięta od krajów graniczacych ze Stowenia (włoska, węgierka, austriacka, ogólnie bałkańska); kuchnia stoweńska korzysta z kuchni sąsiadów (z kuchni austriackiej, chorwackiej, serbskiej itd.); dobre jedzenie zróżnicowane o wptywach austriackich, węierskich, włoskich, potudniowostowiańskich; częściowo bałkańska, częściowo germańsko-włoska; mieszanka kuchni włoskiej, śródziemnomorskiej i austriackiej; mieszanka kuchni austriackiej, wegierskiej $i$ włoskiej oraz batkańskiej.

W części zgrupowanych w tej klasie konkretyzacji mocniej został uwypuklony wpływ tylko kultury Bałkanów i/lub Włoch:

- kuchnia bałkańska; przeważa kuchnia batkańska; tradycyjne bałkańskie jedzenie; batkańskie menu; jest mieszanka potraw pochodzacych z krajów batkańskich (np. burek, čevapčiči i); potrawy zaczerpnięte z takich krajów jak Chorwacja, Bośnia i Hercegowina;

- stoweńska kuchnia kojarzy mi się głównie z burkiem i włoska kuchnia; mieszanka kuchni batkańskiej i włoskiej; stoweńska kuchnia jest bardziej zróżnicowana niż nasza, widać wpływy włoskie i batkańskie; stoweńska kuchnia to głównie wptywy włoskie i batkańskie;

- $\quad$ W Wtoch przybyty chyba wspaniate lody i desery; jadaja potrawy wtoskie; jedza dużo wtoskiego jedzenia: cannelloni, njoki, pizza, spagetti $i$ wiele innych; styszałam od Stoweńca, że ich narodowym daniem jest... pizza.

Trzeba dodać, że wprawdzie na kulinarne upodobania Słoweńców i to, co gości na ich stole, znaczący wpływ miała kuchnia krajów ościennych, jednak ze względu na obecność w innej, bo słoweńskiej, kulturze - nabrawszy lokalnego charakteru, przygotowywane są nieco odmiennie.

Niewielka obecność w słoweńskim menu potraw typowo narodowych wiąże się również z dostrzeżonym przyjęciem przez mieszkańców kraju nad Drawą, Sawą, Murą i Soczą postawy otwartej, również na nowsze wpływy (łącznie 4\%): dużo restauracji nawiąujacych do kuchni innych narodów; bardzo chętnie inspiruja się potrawami innych kultur - np. w Stowenii na każdym kroku można spotkać pizzerie, chińskie restauracje, meksykańskie, brazylijskie. Jak zauważają ankietowani, taka sytuacja może być wynikiem szeroko rozumianych procesów unifikacyjnych, również związanych z globalną komercjalizacją: obecnie jak we wszystkich krajach [słoweńska kuchnia] ulega rewolucji dzięki dostępności mediów; potrawy rozpowszechnione wszędzie w Europie. Szczególnie podkreślano efekt makdonaldyzacji i związaną z nim powszechność barów szybkiej obsługi (choć nie tylko rodem z USA): w pośpiechu zdarza im się sięgać po positki serwowane $w$ restauracjach typu fast-food; dziś, jak we wszystkich społeczeństwach zachodnich, także w Stowenii możemy spotkać jedzenie typu fast food np. hambur-

${ }^{5}$ Objaśnienie potraw znajduje się w dalszej części artykułu. 
gery, pizzę; bardzo dużo pizzy (z bardzo dziwnie łączonymi składnikami-praktycznie żadna nie jest zrobiona tak, jak być powinno, a więc tak jak w Polsce); kebab.

Pomimo łatwej dostępności do „śmieciowego" jedzenia, na słoweńskim stole często goszczą potrawy świadczące o przywiązaniu do zdrowego trybu życia, troski o pełnowartościowe pokarmy i związane z tym mody żywieniowe ${ }^{6}$. Taki stan rzeczy wynika m.in. z propagowanego w Słowenii - i przez wielu jej mieszkańców praktykowanego - zdrowego stylu życia, kultu witalności oraz postaw proekologicznych. Model ten potwierdza nie najmniejsza grupa ekscerptów (6\%): potrawy zdrowe; poświęcaja sporo uwagi jakości produktów, częściej wybieraja te naturalne; produkty naturalne (praktycznie każdy ma jakieś ulubione rzeczy, których nie kupuje w zwyklym sklepie, tylko przywozi z domu lub kupuje u znajomych producentów; wszystko, co jest „eko”; moda na żywność ekologiczna, zdrowa; modne jest jednak bycie eko i fit, więc popularne sa sklepy z ekologiczna żywnościa, mleko roślinne itp.; duża wage przywiazuja [...] do zdrowego odżywiania, wielu z nich stosuje jakass diete (wegetarianizm, „presna hrana” itp.); bardzo łatwo dostać tu smaczne wegetariańskie $i$ wegańskie jedzenie.

Wielowiekowa zależność narodu słoweńskiego od dużych mocarstw oraz wieloletnie istnienie w ramach federacji południowych Słowian, rola kuchni sąsiadów znacząco przyczyniły się do marginalizacji narodowego potencjału kulinarnego Słoweńców. W zebranym materiale bywała wprost wyrażana trudność w dostrzeganiu słoweńskiej l'art culinaire, a nawet negacja jej istnienia (3\%): niemal całkowity brak tradycyjnej kuchni słoweńskiej; niewiele jest potraw typowo stoweńskich; nie jadtam nic typowo słoweńskiego; typowo słoweńskiej kuchni chyba nie ma...; praktycznie przez cały wyjazd nie mogłam odnaleźć restauracji z typowymi słoweńskimi potrawami. Pytani przeze mnie Stoweńcy nie potrafili wskazać takich miejsc; trudno powiedzieć, jaka potrawa jest typowo stoweńska; trudno mi ocenić, czy znalazłam coś specjalnie słoweńskiego podczas mojego sześcioletniego pobytu tutaj. Mam wrażenie, że ,wszytko już gdzieś jadtam i widziatam" tylko pod inna-obcojęzyczna - nazwa.

Niewielki odsetek ekscerptów obrazuje inne (różne - 2\%) ogólne cechy kuchni Słoweńców: słoweńska kuchnia jest różnorodna; kuchnia niespecjalna; ich umiejętności gotowania: większość potrafi coś ugotować; a także realia Polaków doświadczających szeroko rozumianych słoweńskich kulinariów: określenie „polska gościnność” przestała dla mnie znaczyć cokolwiek po doświadczeniu stoweńskiej gościnności; wiele towarzyskich rozmów toczy się tu właśnie wokót jedzenia; $w$ sklepach jednak dramat - bardzo mało produktów; gotować coś w Stowenii na własna ręke jest ciężko?.

${ }^{6} \mathrm{O}$ słoweńskim przywiązaniu do zdrowia świadczą również choćby dane na temat sposobu spędzania wolnego czasu (Wacławek, Wtorkowska 2017a).

${ }^{7}$ Ostatnie cytaty obrazują studencką perspektywę. 


\section{KONKRETNE DANIA, SKLADNIKI, PRZYPRAWY, NAPOJE ITP.}

Niewiele ponad połowę (52\%) wszystkich ekscerptów budujących obraz tego, co gości na stole w Słowenii, widziany z perspektywy polskich respondentów, współtworzą dane językowe malujące bogaty wachlarz konkretnych dań, ich składników, przypraw i napoi. Stanowi to dobrą egzemplifikację nie tylko pokarmów, ale również tego, co kulturowo determinuje tożsamość mieszkańców niewielkiego kraju sąsiadującego z Węgrami, Austrią, Chorwacją i Włochami.

Pisząc o sztuce gotowania, badacze kultury wyróżniają m.in. akt kulinarny, na który składają się trzy podstawowe elementy: dobór składników, przetwarzanie ich w pokarm oraz jego spożycie w formie gotowej potrawy (Żarski 2012, s. 77). Granica między tym, co jest gotowym daniem, jego składnikiem, produktem do jego przyrządzenia czy poprawy smaku, często bywa płynna. Kategoryzacja i opis należącej do tej grupy ekscerptów mogą wzajemnie się przenikać, dlatego zdecydowałyśmy się na wspólną ich charakterystykę. Bywało, że podawane przez respondentów nazwy zapisywano po słoweńsku z zachowaniem oryginalnej lub spolszczonej pisowni (typu pršut / prszut). Wprowadzenie takiego „kolorytu lokalnego" najlepiej oddawało intencję piszących.

Zaskakująco niski był odsetek użycia nazw zup, które jadane są w Słowenii (zaledwie 1\%). Polscy respondenci ograniczyli się w zasadzie tylko do jednego jej rodzaju: dobre zupy, rosół z wołowiny; goveja juha [rosół wołowy]. Jest wiele przyczyn rzadkich i jednorakich poświadczeń nazw potraw, które uznawane są za pierwsze danie obiadu. Jedną z nich może być to, że w opinii Polaków (czy ogólnie wszystkich) Słoweńcy rzeczywiście mało spożywają tego typu dań. Potwierdza to wypowiedź jednej z Polek na stałe mieszkającej w kraju ze stolicą w Lublanie: „Słoweńcy lubują się tylko w rosole, bardzo rzadko [na stołach gości] zupa jarzynowa, ale nazywa się »enolončna«, czyli jeden garnek [potrawa jednogarnkowa]" (Cmiel i in. 2008, s. 45). Inne powody absencji można w uproszczeniu sprowadzić do dwóch głównych: a) słoweńskie zupy, których kosztowali Polacy, mogły być w ich opinii na tyle podobne czy też uniwersalne (zupa pomidorowa, szpinakowa, grzybowa, cebulowa itd.), że nie zostały uznane za dobro narodowe Słowenii, b) respondenci sami rzadko spożywają zupy, więc nie doceniają ich wartości i nie zauważają ich obecności - co może być ogólniejszą (nie tylko polską) tendencją.

Bogatszy obraz rysuje się na podstawie poświadczeń o kaszach i różnych daniach mącznych (7\%): kuchnia oparta na kaszach; jako ciekawostke odbieram wykorzystanie mąki kukurydzianej, potrawy tzw. polenty; $z$ dań niesłodkich 
sq m.in.: njoki ${ }^{8}$, polenta, mąka gryczana; ajda; ajdovi žganci $i^{9}$; za najbardziej stoweńskie uchodza: [...] prażucha z mąki gryczanej; makarony; makarony z sosami mięsno-pomidorowymi pochodzace z Włoch; pizza; štruklji ${ }^{10}$; burek ${ }^{11}$; domowy chleb. Powyższe wyliczenia świadczą z jednej strony o sygnalizowanej już roli kultury ludowej - chłopskich potraw (opartych m.in. ma różnego typu kaszach, kaszkach i mąkach, np. gryczanej i kukurydzianej), jak i nadmienionych zapożyczeń kulinarnych, a więc naznaczeniu pokarmów występujących na słoweńskich stołach bliskością sąsiadów (njoki, makarony, burek itd.).

Oba te czynniki korelują z obrazem słoweńskiej konsumpcji mięsa i wędlin (4\%). Współtworzą je zarówno ogólne uwagi: bardzo dużo spożywa się mięsa; mięsa siekane przygotowywane na ruszcie na sposób bałkański; grillowane mięso; drogie mięso, często przetworzone w sposób budzacy wątpliwości; jak i wskazania konkretnego niewegetariańskiego dania: ričet ${ }^{12}$ z parówka; čevapčiči ${ }^{13}$, czetapczicze; dunajski zrezek ['sznycel wiedeński' - czyli kotlet schabowy]; i wędlin: krańska kietbasa; poza tym jako specjalność stoweńska odbieram prszut; pršut ${ }^{14}$; domowe wędliny.

Wprawdzie Słowenia jako kraj ma bardzo mały dostęp do morza (niespełna $47 \mathrm{~km}$ ), ale wpływy śródziemnomorskiego stylu życia i sposobu odżywiania (zwłaszcza w regionie nadmorskim) są mocne - co z różnym nasileniem znalazło odbicie w wynikach badań. Część ekscerptów współtworzy obraz słoweńskiego zamiłowania do spożycia różnego rodzaju ryb (również słodkowodnych) oraz owoców morza (3\%): zdecydowanie większy wybór (świeżych) ryb; potrafia przyrzadzić świetnie rybę; specjaty to ryby, smaczne ryby z dodatkami; dla Polaka w Stowenii jest zadziwiająca, i dla amatorów zachwycająca, dostępność ryb i owoców morza; kalamari [kalmary].

${ }^{8} \mathrm{Njoki}$ (wł. gnocchi) to potrawa pochodząca z Włoch, przygotowywana najczęściej z ziemniaków lub sera i mąki, podobna do polskich kopytek.

${ }^{9}$ Ajdovi žganci to danie na bazie mąki białej i gryczanej z wodą, solą i skwarkami.

${ }^{10} \check{S}$ truklji to ciasto z nadzieniem, zwinięte w roladę, jest tradycyjnym słoweńskim daniem serwowanym jako dodatek do mięs i sosów albo osobno jako deser. Wyróżnia się różne jego rodzaje: ze względu na sposób gotowania, typ ciasta oraz rodzaj nadzienia (orzechowe, serowe, jabłkowe, estragonowe), które może być słodkie lub słone.

${ }^{11}$ Burek to powszechne na Bałkanach (a przybyłe z Turcji) vlečeno testo, czyli cienkie warstwowe ciasto niedrożdżowe, nadziewane mielonym mięsem (burek) czy farszem z białego sera (sirnica) lub ziemniaków (krompiruša) albo szpinakiem (zeljanica). W Słowenii wszystkie wymienione rodzaje określa się jako burek; również sprzedawany jest wariant o smaku pizzy (pizza burek).

${ }^{12}$ Ričet to danie jednogarnkowe z gotowanej kaszy jęczmiennej, niewielkiej ilości fasoli, wędzonych wieprzowych żeberek i warzyw oraz przypraw.

${ }^{13}$ Čevapčiči to klasyczne mięsne danie bałkańskie z grilla, przygotowane z mięsa mielonego, uformowanego w podłużne kiełbaski. Podaje się je najczęściej z cebulą i kajmakiem (świeżym serem) lub ajvarem (por. przyp. 18), często też w bułce typu lepinja. Čevapčiči pochodzą z Bośni, dokąd przywędrowały z kuchni tureckiej.

${ }^{14}$ Pršut to specjalnie wędzona i suszona na wietrze szynka pochodząca z Krasu (obszar słoweńskiego i włoskiego płaskowyżu), świetnie nadająca się na przystawkę. W Polsce znana jest podobna pochodząca z Włoch szynka parmeńska (prosciutto di Parma). 
Ze wspomnianą typowo słoweńską (chłopską) kuchnią wiążą się zaś - rzadko poświadczane w zebranym materiale - dania na bazie ziemniaków, kapusty czy fasoli (3\%): svaljki ${ }^{15}$; pewnie , matevž" ${ }^{16}$ (ale ten jest niespecjalnie smaczny $i$ [niezbyt] lubiany nawet wśród Stoweńców); ,jota" ${ }^{17}$ (podobna do polskiego kapuśniaku); zelje [kapusta]; kuchnia oparta na [...] fasoli; poza tym: nie ma tak wszechobecnych jak $w$ Polsce gotowanych ziemniaków - ziemniaki częściej niż u nas przyrzadza się na różne sposoby, częściej też widzę ryż i inne dodatki.

Respondenci nierzadko wspominali o innych warzywach, a także o owocach (łącznie 8\%). Zasadniczo w porównaniu z nawykami żywieniowymi Polaków (Wacławek, Wtorkowska 2018d) w menu Słoweńców więcej [jest] owoców $i$ warzyw. Z jarzyn szczególnie chętnie wskazywano na te, z których można przyrządzić sałatkę (zwłaszcza ze świeżych składników): dużo warzyw i sałatek; sałatki; zielona sałata; dużo sałaty przyprawionej octem; sałata z octem jabtkowym; godne pochwaty sa wszędobylskie zielone sałaty i inne sezonowe „trawy” (rukola, mniszek...) zaprawione octem - mniam; regrat (mniszek); poza tym lubiana jest kisla repa [kiszona rzepa] i popularne [sa] pasty pomidorowo-paprykowe, $n p$. ajvar ${ }^{18}$. Wśród zarejestrowanych ekscerptów dotyczących stricte owoców pojawiły się m.in: pyszne owoce, świeże figi, winogrona; owoce z ekologicznych upraw, $z$ własnego sadu. Odnotowałyśmy również uwagę krytyczną związaną z wysokimi cenami też sezonowych owoców i warzyw, sprzedawanych na targu: na rynku / targu [są] bardzo drogie owoce $i$ warzywa, nawet te sezonowe, dużo droższe niż w sklepach. Wśród innych jednokrotnie zarejestrowanych ekscerptów podano lubiane przez Słoweńców pieczone kasztany; poza tym $z$ darów natury ceni się [...] grzyby. Te ostatnie uznawane są przez znawców słoweńskiej sztuki kulinarnej za nieodłączny składnik kuchni tego kraju ${ }^{19}$.

Pewną grupę ekscerptów współtworzą konkretyzacje innych produktów spożywczych, w tym przypraw (5\%), które respondentom wyraźnie kojarzą się ze słoweńską sztuką kulinarną:

${ }^{15}$ Krompirjevi svaljki to danie podobne do polskich kopytek, przygotowywane z gotowanych ziemniaków, soli, jajka i masła. Gotuje się je w osolonej wodzie lub smaży na oleju. Świetne są jako dodatek do gulaszu lub kiszonej kapusty i steków w sosie. Można je również podawać na słodko (często z sosem owocowym).

${ }^{16}$ Matevž to tradycyjne słoweńskie danie przygotowane z tłuczonych ugotowanych ziemniaków i fasoli, do których dodajemy czosnek, olej z oliwek, pieprz i sól, najczęściej jest podawany z kiszoną kapustą albo rzepą i mięsnym dodatkiem, np. pieczoną kiełbasą, pieczonymi żeberkami lub plastrem gotowanej wędzonej szynki albo tylko okraszone skwarkami. Można go również serwować jako dodatek zamiast purée.

${ }^{17}$ Jota - danie jednogarnkowe z gotowanej kiszonej kapusty, ziemniaków i fasoli z dodatkiem wędzonych wieprzowych żeberek, cebuli i skwarek oraz przypraw.

${ }^{18}$ Ajvar - przyprawa w formie przecieru z papryki, którą można podać do mięsa (na przykład do čevapčičy czy pleskavicy) zamiast lub obok musztardy. Jada się również chleb posmarowany ajvarem. To przyprawa bałkańska, która dotarła na ziemie słoweńskie po II wojnie światowej. Umiłowanie do ajvaru występuje głównie wśród Serbów i Macedończyków.

${ }^{19}$ Jedną ze stereotypowych czynności wolnoczasowych Słoweńców jest zbieranie grzybów (Wacławek, Wtorkowska 2017a). 
- ważny jest dla nich miód - maja wielu pszczelarzy (a pszczoła i ul to dla mnie jeden z nieoficjalnych symboli tego kraju); miód $i$ wyroby pszczelarskie; miód (mam wrażenie, że tutaj każdy ma w rodzinie przynajmniej jednego pszczelarza); miód z własnej pasieki;

- chyba wszyscy używaja soli morskiej i oleju z pestek dyni; oliwa z dyni; olej z dyni (bučno olje); ocet jabtkowy; wtasny ocet.

Nie zawsze typowo słoweński sposób przyprawiania posiłków przypadał do gustu polskiemu podniebieniu: mniej przyjemnym skojarzeniem jest ocet, ponieważ odniostam wrażenie, ̇̇e Stoweńcy nadużywaja tej substancji; trudno przyzwyczaić mi sie jednak do octu - dodaja go do gotowania warzyw (np. kalafiora, fasolki szparagowej), takie połaczenie jest dla mnie niespecjalne; vse je lahko kislo [wszystko jest kiszone, kwaśne - również w znaczeniu przyprawione octem].

$\mathrm{Z}$ pewnością przez polskich respondentów docenione zostały różnorodne desery, spotykane w kraju Petera Prevca; znalazło to odbicie również w częstości tego typu wskazań $(10 \%)^{20}$. Uwag ogólnych było mało: lubia słodycze, ciasta; domowe wypieki. W większości podawano nazwy konkretnych słodkości: za najbardziej stoweńskie uchodza: potica ${ }^{21}[\ldots]$; orehova potica; kremsznita ${ }^{22}$; blejske kremšnite; gibanica ${ }^{23}$; gibanica to wspaniały deser; z deserów typowych dla nich trzeba wymienić: orehova potice, prekmurska gibanice, blejska kremšmite czy (austiacki) jabolčni zavitek [strudel z jabłkami] lub (włoska) panę cotę; inne: naleśniki z czekolada; čokolino ${ }^{24}$.

Największy odsetek danych językowych, bliski wskazaniom deserów, dotyczył obrazu napoi (głównie trunków) - 11\% wszystkich ekscerptów ${ }^{25}$. Niewielka część z tych konkretyzacji współtworzy wizerunek niewyskokowych płynów spożywanych w Słowenii (2\%): normalne jest tu picie wody prosto z kranu; czysta woda (piję tu kranówę i mam się dobrze); mitośnik kawy; Stoweńcy pija dużo mleka; wiele osób $w$ domu sama produkuje [...] soki. Podobnie jak w wielu

${ }^{20}$ Jeden raz wyrażono dezaprobatę w stosunku do typowo słoweńskich łakoci: ich ciasta i desery, gibanica i kremšnita, to nie sa rzeczy, które lubię.

${ }^{21}$ Potica, przez niektórych nazywana ,ambasadorką Słowenii”, uważana za królową ciast, to jedno $z$ oryginalnych słoweńskich wypieków. Jest ciastem drożdżowym zwiniętym w sposób podobny do rolady. Zwykle ma nadzienie z orzechów i rodzynek, może być również z makiem albo estragonem, rzadziej czekoladą.

${ }^{22}$ Kremna rezina (kolokwialnie kremšnita) jest kremówką z francuskiego lub półfrancuskiego ciasta posypaną cukrem pudrem. Najlepsze tego typu desery pochodzą z miasta Bled (blejska kremšnita).

${ }^{23}$ Gibanica jest ciastem wywodzącym się z regionu Prekmurje. Wypiek składa się z ,ppofalowanych" warstw (spód stanowi kruche ciasto, następnie warstwy z ciasta „ciągnionego" kilkakrotnie oddziela nadzienie: makowe, serowe, orzechowe i jabłkowe, na końcu kładzie się kwaśną śmietanę).

${ }^{24}$ Čokolino to znana w Słowenii kaszka zbożowa dla dzieci o smaku czekolady, najczęściej rozpuszczana w mleku, chorwackiej firmy Podravka (znanej również z produkcji Vegety).

${ }^{25} \mathrm{O}$ znaczeniu napoi w kulturze Słoweńców świadczy również jeden z ich modeli spędzania wolnego czasu - nierzadko przy kawie lub winie (Wacławek, Wtorkowska 2017a). 
krajach w restauracjach woda (zamiast / obok wina) podawana jest do obiadu, a w kawiarniach do popijania innych napoi (wszystkich rodzajów kawy, często też herbaty). Zamiłowanie do kawy Słoweńcy przejęli zarówno z kultury Włoch, jak i Bałkanów.

Większość zebranych okazów współtworzy wyobrażenie wypijanych przez potomków France Prešerena trunków (9\%). Część danych dotyczy ogólnej tendencji narodu do spożycia, a także produkcji alkoholi: alkoholu pija się dużo, jednak Stoweńcy maja większe wyczucie w piciu trunków; mnóstwo ludzi, których znam produkuje własne alkohole, to jest tez rzecz, która kojarzy mi się ze Stowenia. Alkohol jest dużo lepszy niz w innych krajach Europy; alkohol domowej roboty, podobnie jak w Polsce; destylaty owocowe ${ }^{26}$.

Ze względu na unikalne warunki mikroklimatyczne i właściwości gleby uprawa winorośli i tradycja wyrobu „napoju bogów” na ziemiach Słowenii sięga jeszcze czasów przedrzymskich. Oto przykładowe konkretyzacje dotyczące tego trunku: wytwarzanie bardzo dobrych win; jest tu kultura picia wina; lubia pić wino; własne wino; martinovanje ${ }^{27}$; dobre wino, winnice (refoš $k^{28}$, teran ${ }^{29}$, muškat...); cviče $^{30}$. Alkohol (najlepiej domowy) podawany jest zwyczajowo do większych posiłków (obiad, kolacja).

Kilkakrotnie zwerbalizowano również spożycie piwa. Pewna popularność „złotego trunku” jest efektem wielowiekowej zależności od północnego sąsiada ${ }^{31}$. Oto przykładowe werbalizacje: pija piwo równo, zreszta się nie dziwię, skoro w Stowenii kiedyś byto tylko „Laško” $i$, Union”, a teraz tych piw jest mnóstwo; myśla, że robia dobre piwo i że maja duży wybór tego alkoholu, ale to świadczy o tym, że nie maja dostęu do polskiego piwa.

Lingwiści podkreślają bezpośredni związek między leksyką języka danej wspólnoty a jej życiem oraz dziedzictwem duchowym i materialnym. Jak pisze

${ }^{26}$ Oprócz znanej również Polakom śliwowicy, popularne są tu również gruszkówka i jabłkówka.

${ }^{27}$ Martinovanje to zwyczaj świętowania (11 listopada na św. Marcina) przejścia młodego wina, jeszcze o niskiej zawartości alkoholu, w pełnowartościowe, dojrzałe.

${ }^{28}$ Refošk jest autochtonicznym rodzajem czerwonego wina, charakterystycznym dla regionu Słowenii o nazwie Primorska. To ciemnofioletowego koloru wino ma kwaśnawy smak malin i porzeczek.

${ }^{29}$ Teran - to rdzenne czerwone wino z Krasu (południowo-zachodniego regionu Słowenii graniczącego z Włochami). Z powodu specyficznej ziemi na tym obszarze teran ma dużą zawartość kwasu mlekowego. Ma właściwości lecznicze - działa jako przeciwutleniacz, hamuje niedokrwistość (zawiera dużo żelaza), obniża cholesterol i hamuje arteriosklerozę.

${ }^{30}$ Cviček jest jasnoczerwonym winem produkowanym $\mathrm{z}$ winorośli uprawianych $\mathrm{w}$ regionie Dolenjska (południe Słowenii). To jedno z dwóch win na świecie, które wytwarza się na bazie białych i czerwonych winogron. Jego nazwa jest objęta ochroną. Ma niewielką zawartość alkoholu (8,5 do 10\%) i lekko kwaśny smak. Pasuje do wszystkich rodzajów potraw. Cvičkowi przypisuje się działania zdrowotne: z powodu wysokiej zawartości kwasu, jest szczególnie polecane dla cukrzyków. Dobrze działa na przemianę materii, pobudza apetyt, likwiduje bezsenność i wzmacnia krążenie.

${ }^{31}$ Napój chmielowy głównie pity jest na słoweńskiej części terenów dawnych Austro-Węgier (regiony Styria i Kraina). 
Elżbieta Tabakowska (2001, s. 185): „Ogromna większość słów w każdym języku posiada złożone i zwykle typowe dla danego języka znaczenia, co często można traktować jako odzwierciedlenie specyficznego doświadczenia historycznego i kulturowego danej społeczności językowej”. Przykładów zewnętrznego przejawu owej empirii „dostarcza słownictwo związane z jedzeniem i piciem” (Wierzbicka 2007, s. 16). W tworzeniu mentalności danej grupy narodowej, etnicznej czy regionalnej rola kuchni i stołu jest zatem niezwykle istotna. „Wzorce i normy kulinarnego obyczaju stanowią [...] ważny element kodu kulturowego, za pomocą którego naród, społeczeństwo się porozumiewa i samookreśla" (Witaszek-Samborska 2005, s. 7). Nie należy o tym zapominać również w procesie glottodydaktycznym, włączając leksykę szeroko pojętych kulinariów, w szczególności uwzględniając elementy odmienne, charakterystyczne tylko dla danej społeczności i języka. Takie podejście w perspektywie długofalowej ma na celu kształtowanie kompetencji interkulturowych / transkulturowych (Białek 2009, s. 30; Baran 2015).

Część kulturowo uwarunkowanej leksyki słoweńskiej stanowią na pewno wyrazy nazywające pożywienie takie, jak: potica, gibanica czy matevž. Słownictwo kulinarne, w tym nazwy potraw właściwe danej wspólnocie, nie tylko świadczą o dziedzictwie kulturowym, ale również istnieniu pojęć (słów) kluczy (Wierzbicka 2007; Niewiara 2017) niepowtarzalnych dla danego języka i ważnych dla tych, którzy pragną go poznać i zrozumieć. Taka leksyka przynależy do słoweńskiej linguakultury (Zarzycka 2004). Ma to znaczenie i stanowi wyzwanie zarówno dla tłumaczy, jak i lektorów języków obcych, pełniących rolę pośredników kulturowych (Miodunka 2004, s. 107). Na pewno więc warto, a nawet trzeba zapoznać z nim uczących się, aby mówić o pełni doświadczania smaku języka, ponieważ to właśnie w nim odzwierciedla się bogate zaplecze kulturowe danej społeczności.

Słownictwo związane z kuchnią jest wdzięcznym obiektem eksploracji ${ }^{32}$. Słoweńska sztuka kulinarna nie zamyka się w ścisłych granicach, jest efektem wielorakich interferencji - wzbogacania się dzięki kulinarnym zapożyczeniom. Zachowała jednak swój specyficzny, lokalny charakter. Procesy kulturowej unifikacji, integracji, europeizacji czy globalizacji wydają się nieuchronne, były, są i będą, choć oprócz dobrych stron, mają też słabsze. Z pewnością w dążeniu do wspólnoty warto znać, badać i pielęgnować własne tradycje, też kulinarne, dzięki temu w jedności możemy ocalić jakże atrakcyjną różnorodność.

${ }^{32}$ Potrzebne są również badania w ujęciu autostereotypowym (por.: Wacławek, Wtorkowska b). 


\section{BIBLIOGRAFIA}

Baran M., 2015, Podejście skierowane na działanie w nauczaniu języka polskiego jako obcego, „Polski w Niemczech. Pismo Federalnego Związku Nauczycieli Języka Polskiego”, nr 3, s. 60-66.

Bartmiński J., 2007, Stereotypy mieszkają w języku. Studia etnolingwistyczne, Lublin.

Bartmiński J., 2009, Językowe podstawy obrazu świata, Lublin.

Białek M., 2009, Kształcenie międzykulturowe w edukacji językowej, Wrocław.

Borysławski R., 2002, Posmak niedosytu. Kultura jedzenia, jedzenie kultury, „Er(r)go. Teoria. Literatura. Kultura", nr 1, s. 139-142.

Brillat-Savarin A., 2015, Fizjologia smaku albo Medytacje o gastronomii doskonałej, wybór oprac. W. Zawadzki, thum. i wstęp J. Guze, Warszawa.

Cmiel M., Kołeczek A., Lament P., Pieńkowska A., Stachowiak A., 2008, Polacy w Słowenii, Warszawa.

Miodunka W., 2004, Kompetencja socjokulturowa w nauczaniu języka polskiego jako obcego. Zarys programu nauczania, w: W. Miodunka (red.), Kultura w nauczaniu języka polskiego jako obcego, Kraków, s. 97-117.

Niewiara A., 2017, Stowa klucze kultury jako nazwy pojęć wyrazistych o wysokim stopniu utrwalenia a zagadnienia synonimii leksykalnej, ,LingVaria”, nr 1 (23), s. 223-252.

Skowronek B., 2012, Jedzenie jako tekst kultury: zarys problemu, ,Annales Universitatis Paedagigicae Cracoviensis. Studia Historicolitteraria”, nr 12, s. 281-289.

Szomba-Rosowa Z., 1997, Pożywienie jako znak identyfikacji kulturowej. Z etnograficznych badań na Podhalu, „Studia Małopolskie”, nr 1, s. 71-76.

Tabakowska E. (red.), 2001, Kognitywne podstawy języka i językoznawstwa, Kraków.

USJP = Uniwersalny stownik języka polskiego PWN, T. I-IV, 2008, pod red. S. Dubisza, Warszawa.

Wacławek M., Wtorkowska M., 2017a, Słoweńców spędzanie wolnego czasu - w kręgu badań językowo-kulturowych stereotypów, w: A. Kołodziej (red.), T. Piasecki (współpraca), Słowiańszczyzna dawniej i dziś - język, literatura, kultura Monografia ze studiów slawistycznych III, Červený Kostelec, s. 277-290.

Wacławek M., Wtorkowska M., 2017b, „Stowiański Austriak” - o charakterze Stoweńców słów kilka, ,Jezikoslovni zapiski”, nr 1, s. 193-210.

Wacławek M., Wtorkowska M., 2017c, ,,Stowiański góral spod Alp” - z badań nad auto- $i$ heterostereotypem Sloweńca, w: M. Vojteková (red.), Jazyk v kultúre, kultúra v jazyku. Język w kulturze, kultura w języku, Prešov, s. 176-188.

Wacławek M., Wtorkowska M., 2018a, Czas wolny Polaków - w kręgu językowo-kulturowych stereotypów, w: D. Lech-Kirstein (red.), Bariery i pomosty w języku i kulturze, Opole. [w druku]

Wacławek M., Wtorkowska M., 2018b, Człowiek człowiekowi lustrem - konceptualizacje Polki $i$ Polaka w wypowiedziach polskich i stoweńskich respondentów, w: M. Wtorkowska, M. Wacławek, L. Rezoničnik (red.), Sedemdeset let poučevanja poljskega jezika v Ljubljani, posvečeno Nikolaju Ježu, Ljubljana, s. 259-273.

Wacławek M., Wtorkowska M., 2018c, „Jak ich widza, tak ich piszq” - rzecz o wygladzie Stoweńców, w: J. Tambor (red.), Polonistyka na początku XXI wieku. Diagnozy. Koncepcje. Perspektywy. T. 4. Pogranicza, mniejszości, regiony. Etnolingwistyka, Katowice 2018, s. 271-289.

Wacławek M., Wtorkowska M., 2018d, Przez jedzenie do języka ... polskiego - o kulinariach oczami Polaków i Stoweńców, w: D. Lech-Kirstein (red.), Bariery i pomosty w języku i kulturze, Opole. [w druku]

Wacławek M., Wtorkowska M., a, „Nasz wygląd zależy od tego, w jakim lustrze się przejrzymy” - z badań nad stereotypem Polaka, Zagreb. [w druku] 
Wacławek M., Wtorkowska M., b, Smaki Słowenii - kulinaria w ujęciu autostereotypowym. [w opracowaniu]

Wierzbicka A., 2007, Słowa klucze. Różne języki - różne kultury, Warszawa.

Witaszek-Samborska M., 2005, Studia nad stownictwem kulinarnym we współczesnej polszczyźnie, Poznań.

Zarzycka G., 2004, Linguakultura - czym jest, jak ja badać i „otwierać”?, w: A. Dąbrowska (red.), Wrocławska dyskusja o języku polskim jako obcym. Materiały z międzynarodowej konferencji Stowarzyszenia ,Bristol”, Wrocław, s. 435-443.

Żarski W., 2012, Tożsamość kulinarna na Górnym Ślasku i Opolszczyźnie, „Rozprawy Komisji Językowej WTN", t. 39, J. Miodek, W. Wysoczański (red.), s. 73-86.

\section{Maria Wacławek, Maria Wtorkowska}

\section{TELL ME WHAT YOU EAT AND I WILL TELL YOU WHO YOU ARE ON SLOVENE CULINARY ARTS}

Keywords: culinary arts, stereotype, Slovenia, linguistic worldview

Summary. Culinary arts are an important part of every nation's culture. The goal of our text is to converge the linguistic-cultural view of Slovene culinary arts from a hetero-stereotypical point of view of Polish people. For our analysis, we used operational categories of an ethnolinguistic school from Lublin and its continuators from all over Poland. The article is based on academic surveys. We differentiated and wrote about two thematic circles, which reconstruct Slovene culinary arts: 1) the general characteristics of Slovene cuisine, 2) specific dishes, ingredients, drinks etc. The linguistic worldview captured in the discourse on culinary identity are one of the main factors influencing the cultural identity of a given community. The vocabulary, especially culturally conditioned, regarding the culinary arts should find its place in the glottodidactic process. 